\title{
ANALISIS KEUNTUNGAN AGROINDUSTRI GULA AREN DI KELURAHAN PANDU, KECAMATAN BUNAKEN, KOTA MANADO
}

\author{
Marhaeny Ketty Derek \\ Rine Kaunang \\ Joachim N.K. Dumais
}

\begin{abstract}
The objective of this research is to analyze the benefits received by the palm sugar household industry is in one time production process. This research was conducted in Pandu Village, Bunaken Subdistrict, Manado City. This study was conducted for 3 months from June to August 2017. The data obtained is the primary data obtained from three farmer craftsmen of palm sugar. Based on the result of the research, it can be concluded that the business of oil palm agroindustry in Pandu Urban Village, Bunaken Sub-district, Manado City is very profitable and get value $R / C=2,29$ which means the industry is profitable and feasible to be developed.
\end{abstract}

Keywords: palm sugar, profit analysis, $R$ / C ratio, Pandu Urban Village, Bunaken Sub-district, Manado City

\section{ABSTRAK}

Tujuan penelitian ini adalah menganalisis keuntungan yang diterima industri rumah tangga gula aren di Kelurahan Pandu Kecamatan Bunaken dalam satu kali proses produksi. Penelitian ini dilakukan di Kelurahan Pandu, Kecamatan Bunaken Kota Manado. Penelitian ini dilakukan selama 3 bulan dari bulan Juni sampai bulan Agustus 2017. Data yang diperoleh adalah data primer yang diperoleh dari tiga petani pengrajin gula aren. Berdasarkan hasil penelitian, dapat disimpulkan bahwa usaha agroindustri gula aren di Kelurahan Pandu, Kecamatan Bunaken, Kota Manado sangat menguntungkan dan mendapat nilai R/C= 2,29 yang berarti industri ini menguntungkan dan layak untuk dikembangkan.

Kata kunci: gula aren, analisis keuntungan, R/C ratio, Kelurahan Pandu, Kecamatan Bunaken, Kota Manado

\section{PENDAHULUAN}

\section{Latar Belakang}

Sulawesi Utara menyimpan banyak potensi sumber daya alam serta keanekaragaman hayati yang sangat potensial, untuk pengembangan industri pertanian, termasuk perkebunan yang dapat diolah untuk meningkatkan daya guna sekaligus membuka lapangan pekerjaan bagi masyarakat yang ada didalamnya. Salah satu dari potensi yang dapat diolah adalah tanaman perkebunan pohon Aren atau Enau yang dapat diolah menjadi "Gula Aren".
Tanaman pohon Aren adalah tanaman perkebunan yang sangat potensial dalam hal mengatasi kekurangan pangan dan mudah beradaptasi baik pada berbagai iklim mulai dari dataran rendah sehingga $1400 \mathrm{~m}$ diatas permukan laut (Efendi, 2009).

Pohon aren merupakan pohon yang menghasilkan bahan-bahan industri hampir semua bagian atau produk tanaman ini dapat dimanfaatkan mulai dari akar sampai daun, terlihat bahwa semua dapat diolah menjadi bahan baku produk tertentu dan memiliki nilai ekonomis (Soekartawi, 2001). 
Gula aren diproduksi dengan menggunakan bahan baku dari kelompok tanaman seperti tebu, lontar, nipah dan kelapa. Namun gula aren juga dapat diproduksi dengan bahan baku nira menggunakan teknik pengolahan yang sangat sederhana dan dapat diusahakan pada skala industri rumah tangga. Gula aren diperoleh dari proses penyedapan nira aren yang kemudian dikurangi kadar airnya hingga menjadi padat. Produk gula aren ini adalah berupa gula cetak diperoleh dengan memasak nira aren hingga menjadi kental seperti gulali kemudian mencetaknya dalam cetakan berbentuk setengah lingkaran.

Kelurahan Pandu Kecamatan Bunaken adalah salah satu kawasan pengembangan usaha produk nira (Gula Aren) di Kota Manado. Hal ini didukung oleh faktor alam dan lingkungan juga pertumbuhan dan perkembangan pohon Aren. Di Kelurahan Pandu terdapat 9 pengrajin usaha gula Aren yang sudah lama diusahakan oleh pengrajin, dalam penelitian ini dari 9 pengrajin hanya dipilih 3 pengrajin usaha gula aren karena 3 yang masih aktif. Pengolahan gula Aren di Kelurahan Pandu yang masih menggunakan teknologi yang sederhana. Serta bahan baku yang diperlukan relatif mudah diperoleh, karena bahan baku (air nira) berada di kawasan Gunung Tumpa dan pohon nira tersebut sudah lama ditanam oleh pihak yang ada dan sudah banyak yang bertumbuh sendiri diberbagai tempat yang berada di kawasan Gunung Tumpa di Kelurahan Pandu.

Pada daerah kegiatan yaitu di Kelurahan Pandu produksi gula Aren dilakukan secara tradisional juga didukung oleh metode pembakaran yang menggunakan satu tungku pembakaran. Penggunaaan satu tungku ini memakan waktu yang lama untuk satu kali proses produksi gula Aren yaitu 3-4 jam. Dengan jam kerja mulai dari jam 07.00-08.00am sampai selesai, waktu yang digunakan selama 1 jam dalam pengambilan air nira pada pohonpohon nira tersebut dengan menggunakan penampung air nira yaitu bambu dengan jumlah 4 bambu, setiap pohon nira 1 bambu yaitu untuk menampung air nira. Gula aren yang dihasilkan di Kelurahan Pandu oleh petani berukuran $0,5 \mathrm{~kg} /$ (gula batu), ukuran ini yang diminati oleh konsumen disekitar produksi karena harganya relatif terjangkau. Yang dihadapi oleh petani gula Aren adalah jumlah produksi gula Aren yang relatif sedikit, karena hanya menggunakan satu tungku sebagai tempat memasak gula Aren. sehingga hanya dijual disekitaran produksi walaupun bahan baku nira cukup banyak tersedia disekitar lokasi.

Industri gula Aren di Kelurahan Pandu, merupakan salah satu industri yang mempunyai peranan penting bagi perekonomian masyarakat setempat, Nira aren dijadikan bahan baku utama industri gula Aren yang dikelolah oleh para pengrajin usaha gula Aren untuk pembuatan gula Aren. Produksi nira Aren menjadi bahan baku utama industri dan sangat potensial sebagai bahan baku pembuatan gula Aren pada skala industri kecil.

\section{Rumusan Masalah}

Berdasarkan latar belakang, maka yang menjadi rumusan masalah dalam penelitian ini adalah berapa besar keuntungan yang diperoleh industri rumah tangga gula Aren dalam satu kali proses produksi?

\section{Tujuan Penelitian}

Penelitian ini bertujuan untuk menganalisis berapa keuntungan yang diterima industri rumah tangga gula Aren di Kelurahan Pandu Kecamatan Bunaken Kota Manado dalam satu kali proses produksi.

\section{Manfaat Penelitian}

Manfaat dari penelitian ini adalah agar dapat memberikan informasi bagi pihak-pihak yang memerlukannya untuk menambah wawasan dan pengetahuan yang lebih luas mengenai usaha rumah tangga gula Aren. serta diharapkan dapat digunakan sebagai bahan kajian untuk peningkatan usaha dalam rangka mencapai keuntungan yang maksimal. 


\section{METODE PENELITIAN}

\section{Waktu dan Lokasi Penelitian}

Penelitian ini dilakukan selama 3 bulan, mulai dari tahap persiapan hingga penyusunan laporan yakni mulai bulan Juni Tahun 2017 sampai bulan Agustus Tahun 2017. Lokasi penelitian dilaksanakan di Kelurahan Pandu Kecamatan Bunaken Kota Manado.

\section{Metode Pengambilan Sampel}

Data yang digunakan dalam penelitian ini adalah data primer. Data yang diambil menggunakan teknik wawancara langsung kepada 3 responden dari 9 pengrajin industri rumah tangga gula aren. Data yang ada berupa data primer yang diperoleh melalui wawancara langsung kepada 3 responden dari 9 pengrajin industri rumah tangga gula aren dengan menggunakan daftar pertanyaan yang telah dipersiapkan terlebih dahulu

\section{Metode Pengumpulan Data}

Metode yang digunakan dalam penelitian ini, yaitu metode survey.Data yang digunakan data primer yang diperoleh dari wawancara langsung dengan pengurus dan anggota kelompok tani berdasarkan daftar pertanyaan yang disiapkan serta hasil pengamatan secaara langsung atau survey di tempat penelitan.

\section{Konsep Pengukuran Variabel}

Variabel-variabel yang diukur dalam penelitian ini adalah :

1. Produksi Yaitu, jumlah produksi gula aren yang dihasilkan dalam satu kali produksi dihitung dalam satuan butir.

2. Harga

Harga jual dari produksi gula aren yang dihasilkan dihitung dalam satuan rupiah per butir (Rp/butir).
3. Biaya Produksi Yaitu, besarnya biaya yang dikeluarkan dalam pembuatan gula aren setiap kali produksi yang terdiri dari :

a) Biaya tetap

- Penyusutan alat, yaitu nilai penyusutan selama 1 tahun dari alat-alat yang digunakan. Alat-alat yang digunakan dalam proses pembuatan gula aren seperti wajan, penggayung, bambu penampung air nira, dan tempurung.

Nilai penyusutan dihitung dengan menggunakan metode garis lurus atau straight line method.

b) Biaya Variabel

- Biaya Transportasi, yaitu biaya yang digunakan untuk memasarkan gula aren dari produsen ke konsumen dihitung dalam satuan rupiah per butir (Rp/butir).

c) Biaya Tambahan

Biaya pembantu dalam proses industri ini yaitu berupa kayu bakar, dan sabun cap kodok sebagai anti keasaman air nira saat memasak.

\section{Metode Analisis Data}

Data yang dikumpulkan dalam penelitian ini kemudian dianalisis dengan menggunakan analisis keuntungan yaitu dengan menghitung selisih antara penerimaan dengan biaya yang digunakan. Data yang dikumpulkan akan disajikan dalam bentuk variabel dan dianalisis secara deskriptif. Dan kemudian di lanjutkan dengan rumus Analisis Revenue Cost Ratio $(\mathrm{R} / \mathrm{C})$.

Untuk mengukur benar keuntungan digunakan rumus sebagai berikut :

$\pi=$ TR - TC 
Dimana :

$$
\begin{array}{ll}
\pi & =\text { Profit (Keuntungan) } \\
\mathrm{TR} & =\text { Total Revenue (Total Penerimaan) } \\
\mathrm{TC} & =\text { Total Cost (Total Biaya) } \\
& \text { Kemudian untuk mengetahui apakah }
\end{array}
$$

industri gula aren ini menguntungkan atau tidak dapat digunakan dengan rumus :

$$
\mathbf{a}=\mathbf{R} / \mathbf{C}=(\mathbf{P y} . \mathbf{Y}) /(\mathbf{F C}+\mathrm{VC})
$$

Apabila : $\quad \mathrm{R} / \mathrm{C}=1$, Berarti industri ini tidak untung atau tidak rugi

$\mathrm{R} / \mathrm{C}<1$, Berarti industri ini rugi

$\mathrm{R} / \mathrm{C}>1$, Berarti industri ini untung

\section{HASIL DAN PEMBAHASAN}

\section{Gambaran Umum Lokasi Penelitian Keadaan Geografis}

Kelurahan Pandu adalah salah satu Kelurahan di Kecamatan Bunaken, Kota Manado, Sulawesi Utara. Jarak ditempuh Kelurahan Pandu sampai di pusat kota berkisar $8 \mathrm{~km}$. Luas wilayah Kelurahan Pandu adalah sebesar 159,02 Ha yang terbagi menjadi 8 Lingkungan. (Kantor Kelurahan Pandu, 2014).

Batas-batas Wilayah Kelurahan Pandu sebagai berikut :

Sebelah Utara : Desa Wori, Kecamatan Wori

Sebelah Selatan : Kelurahan Bengkol, Kecamatan Mapanget

Sebelah Timur : Kelurahan Molas, Kecamatan Bunaken, dan

Sebelah Barat : Kelurahan Bengkol, Kecamatan Mapanget

\section{Keadaan Penduduk}

Jumlah penduduk Kelurahan Pandu tahun 2014 sebanyak 5.604 orang, dengan jumlah laki-laki 3.041 orang dan jumlah perempuan 2.563 orang dengan tingkat kepadatan sebesar 388 per $\mathrm{km}$. rinciannya disajikan di Tabel 1.

Mata pencaharian penduduk sebagian besar sebagai petani, disamping itu juga buruh tani. Mata pencaharian penduduk lainnya adalah sebagai Pegawai Negeri Sipil, Pengarijn industri rumah tangga, Pedagang keliling, Peternak, Nelayan, Montir, Dokter swasta, Bidan swasta, Perawat, Pembantu rumah tangga, TNI, POLRI, pensiunan PNS/TNI/POLRI, Pengusaha kecil dan menengah, jasa pengobatan alternatif, Dosen swasta, karyawan perusahaan swasta, tukang, sopir, penjahit, mahasiswa dan rohaniawan dengan jumlah total 1.615 orang.

Tabel 1. Jumlah Penduduk di Kelurahan Pandu Kecamatan Bunaken Kota Manado.

\begin{tabular}{llr}
\hline $\begin{array}{l}\text { Laki-laki } \\
\text { (orang) }\end{array}$ & $\begin{array}{l}\text { Perempuan } \\
\text { (orang) }\end{array}$ & $\begin{array}{r}\text { Total } \\
\text { (orang) }\end{array}$
\end{tabular}

\begin{tabular}{lll}
\hline 3.041 & 2.563 & 5.604 \\
\hline
\end{tabular}

\section{Karakteristik Responden Umur Responden}

Umur dapat mempengaruhi kemampuan seseorang untuk bekerja secara fisik serta dapat menentukan persepsi seseorang. Umur juga dapat mempengaruhi produkstifitas kerja dan peranan dalam proses pengambilan keputusan berbagai pekerjaan yang dilakukan. Umur produktif antar 15 hingga 55 tahun. jumlah responden disajikan pada Tabel 2.

Tabel 2. Jumlah Responden menurut Umur di Kelurahan Pandu Kecamatan Bunaken Kota Manado.

\begin{tabular}{lccc}
\hline No & Umur & $\begin{array}{c}\text { Presentase } \\
(\%)\end{array}$ & $\begin{array}{c}\text { Jumlah } \\
\text { (orang) }\end{array}$ \\
\hline 1 & $30-40$ & 0 & - \\
2 & $40-50$ & 33,33 & 1 \\
3 & $>50$ & 66,6 & 2 \\
\hline Jumlah & & 100 & 3 \\
\hline
\end{tabular}


Tabel 2 menunjukan bahwa sebagian besar petani usaha gula aren berada pada umur $>50$ yaitu 2 orang atau $(66,6 \%)$ dari total responden. Dan di ikuti umur 40-50 yaitu 1 orang $(33,3 \%)$. Jadi rata-rata responden berusia diatas 40 tahun.

\section{Tingkat Pendidikan Responden}

Pendidikan sangat berperan penting dalam menciptakan perubahan dalam kehidupan masyarakat. Pendidikan juga dapat memberikan pemahaman akan baik dan buruk, garis pemisah antara sesuatu yang boleh dan yang tidak boleh dilakukan. Pendidikan dijadikan sebagai salah satu faktor yang menentukan produktifitas kerja, sikap serta kemampuan seseorang dalam berpikir dan bertindak. Berdasarkan hasil penelitian, tingkat pendidikan responden bervariasi mulai dari tingkat Sekolah Dasar (SD), Sekolah Menengah Pertama (SMP), Sekolah Menengah Atas (SMA), dapat dilihat pada Tabel 3.

\section{Tabel 3. Jumlah Responden menurut Tingkat Pendidikan di Kelurahan Pandu Kecamatan Bunaken Kota Manado.}

\begin{tabular}{lccc}
\hline No & $\begin{array}{c}\text { Pendi } \\
\text { dikan }\end{array}$ & $\begin{array}{c}\text { Presentase } \\
(\%)\end{array}$ & $\begin{array}{c}\text { Jumlah } \\
\text { (orang) }\end{array}$ \\
\hline 1 & SD & 66,66 & 2 \\
2 & SMP & 33,33 & 1 \\
3 & SMA & 0 & - \\
\hline Jumlah & & 100 & 3 \\
\hline
\end{tabular}

Tabel 3 menunjukan bahwa responden tingkat pendidikan petani usaha gula aren terbanyak pada tingkat pendidikan SD yaitu 2 orang $(66,6 \%)$. Tingkat responden yang paling sedikit yaitu pada tingkat pendidikan SMP dimana hanya 1 orang $(33,3 \%)$. Jadi rata-rata para petani usaha gula aren hanya kependidikan dasar.

\section{Deskripsi Usaha Industri Rumah Tangga Gula Aren di Kelurahan Pandu Kecamatan Bunaken Kota Manado.}

Kelurahan Pandu Kecamatan Bunaken Kota Manado berada di sebelah utara Desa Wori Kecamatan Wori, di sebelah barat Kelurahan Bengkol Kecamatan Mapanget, di sebelah selatan Kelurahan Bengkol Kecamatan Mapanget dan di sebelah timur Kelurahan Molas Kecamatan Bunaken. Kelurahan Pandu terdiri dari tanah milik Kelurahan Pandu dan Gunung Tumpa yang termasuk kawasan hutan lindung. Di Gunung Tumpa terdapat tanaman tahunan dan tanaman semusim yang dikelola dari berbagai pihak.

Masyarakat disekitar wilayah Gunung Tumpa memanfaatkan tanaman pohon Aren tersebut dengan membuat usaha gula Aren dan dipasarkan sebagai mata pencaharian bagi masyarakat setempat. Masyarakat yang tinggal dilokasinya dibawah Gunung Tumpa ini mengusahakan usaha gula Aren dan mengambilnya secara gratis untuk diusahakan. Alat-alat yang digunakan dalam pengelolaan gula Aren masih sederhana seperti Wajan, penggayung terbuat dari bambu dan tempurung, Penampung air nira terbuat dari bambu, dan tempurung sebagai tempat cetakan gula Aren. Tempat memasak gula Aren yaitu tanah liat yang digali dan menjadi keras.

Pengelolaan gula Aren dilakukan di Gunung Tumpa berdekatan dengan sumber nira sebagai bahan dasar untuk membuat gula aren. Adanya pembangunan perumahan-perumahan untuk masyarakat yang terkena banjir yang berada di Kota Manado menyebabkan pohon Aren dan kayu bakar semakin berkurang.

\section{Produksi, Harga, dan Biaya Produksi \\ Produksi}

Pada dasarnya setiap industri dalam meningkatkan produksinya bertujuan untuk meningkatkan keuntungan yang diterimanya. Hasil produksi yang diperoleh 
dinilai dari biaya yang dikeluarkan dan penerimaan yang diperoleh. Pengrajin 1 produksi gula Aren yaitu sebanyak 30 (gula batu), Pengrajin 2 produksi gula Aren yaitu sebanyak 35 (gula batu), Pengrajin 3 Produksi gula Aren sebanyak 50 (gula batu). Berat gula Aren / (gula batu) berkisar antara 450 gram hingga 550 gram dengan berat rata-rata 500 gram (gula batu).

\section{Harga Jual}

Harga merupakan persetujuan antara pembeli dengan penjual dalam satu produk tertentu. Untuk harga / (gula batu) pada pengarjin 1 yaitu Rp. 8.000 (gula batu), pada pengrajin $2 \mathrm{Rp} .10 .000$ (gula batu), dan pengarajin 3 Rp.10.000 (gula batu).

\section{Biaya Produksi}

Biaya produksi merupakan keseluruhan biaya yang digunakan untuk membiayai keseluruhan proses usaha tersebut. Biaya produksi untuk mengelolah gula aren terdiri dari biaya variabel (Variable Cost) dan biaya tetap (Fixed Cost). Dalam penelitian ini menunjukan bahwa dalam kegiatan produksi gula aren, petani mengeluarkan beberapa biaya untuk menunjang kegiatan produksi yaitu biaya tetap, berupa biaya penyusutan alat, dan biaya variabel berupa biaya transportasi (pembelian bensin). Untuk pengadaan bahan bakar berupa kayu bakar pengrajin mengeluarkan biaya. Biaya bahan baku air nira petani gula Aren di Kelurahan Pandu tidak mengeluarkan biaya dikarenakan nira aren yang digunakan oleh petani adalah milik sendiri atau hasil dari penyedapan pohon Aren milik petani gula Aren, Tetapi dengan melalui pendekatan untuk menghitung bahan baku air nira cara menghitung berapa bambu yang digunakan dalam satu hari, diwaktu pagi dan sore dan dan dihitung berapa ruas dalam satu bambu kemudian dihitung dalam ukuran liter dan akan dilihat berapa liter air nira yang tertampung didalam satu ruas bambu.

\section{Biaya}

\section{Biaya Tetap}

Biaya tetap (FC) yang dimaksud dalam penelitian ini adalah biaya yang tidak habis dalam satu kali proses produksi, tetapi hanya mengalami penyusutan atau yang disebut sebagai biaya investasi seperti pengadaan peralatan. Untuk menunjak keberlangsungan industri pembuatan gula aren. Biaya tetap dalam pembuatan usaha gula aren diperhitungkan sebagai penyusutan kerja dari alat-alat produksi yang digunakan dalam memproduksi gula aren. Penyusutan dapat dihitung berdasarkan umur ekonomis dari alat-alat produksi. Untuk mengetahui nilai ekonomis dari masing-masing peralatan yang digunakan dalam pembuatan gula aren, maka dihitung nilai penyusutan dalam satu kali proses produksi.Penyusutan dihitung menggunakan metode garis lurus yaitu nilai awal dari peralatan dikurangi dengan nilai sisa kemudian dibagi dengan umur ekonomis dari peralatan tersebut. Nilai awal diperoleh dari biaya yang digunakan untuk membeli peralatan tersebut sedangkan umur ekonomis dilihat dari lamanya penggunaan peralatan tersebut masih menguntungkan. Untuk lebih jelasnya mengenai penyusutan biaya tetap dalam penelitian ini dapat dilihat pada Tabel 4.

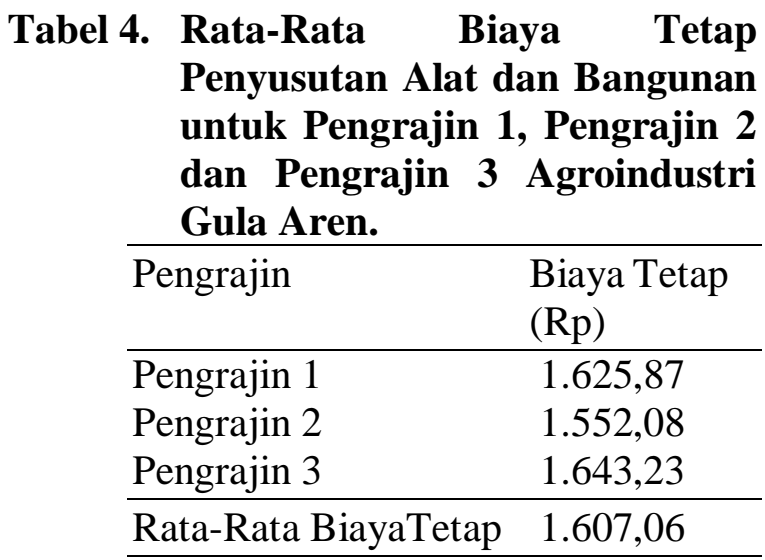

Tabel 4 memperlihatkan bahwa ratarata biaya tetap penyusutan alat dan 
bangunan untuk Pengrjin 1, Pengrajin 2, dan Pengrajin 3 Agroindustri gula Aren di Kelurahan Pandu Kecamatan Bunaken adalah sebesar Rp. 1.607,06.

\section{Biaya Penyusutan Alat}

Penyusutan alat merupakan biaya yang perlu dimasukan kedalam perhitungan biaya tetap. Biaya penyusutan alat yaitu pengurangan nilai yang disebabkan oleh pemakaian alat selama proses berlangsung. Penyusutan yang dihitung adalah umur teknis alat berdasarkan pemakaian alat-alat produksi milik sendiri. Dapat di lihat pada Tabel 5.

Tabel 5. Total Nilai Penyusutan Alat dan Bangunan yang digunakan dalam Produksi pada Pengrajin 1, Pengrajin 2, dan Pengrajin 3 Agroindustri Gula Aren.

\begin{tabular}{lcccr}
\hline $\begin{array}{c}\text { Alat-alat } \\
\text { Produksi }\end{array}$ & $\begin{array}{c}\text { Peng1 } \\
(\mathrm{Rp})\end{array}$ & $\begin{array}{c}\text { Peng } 2 \\
(\mathrm{Rp})\end{array}$ & $\begin{array}{c}\text { Peng3 } \\
(\mathrm{Rp})\end{array}$ & $\begin{array}{r}\text { Rata-Rata } \\
(\mathrm{Rp})\end{array}$ \\
& & & & \\
Pondok & 434,03 & 347,22 & 347,22 & 376,16 \\
Tungku & 104,17 & 104,17 & 104,17 & 104,17 \\
Wajan & 381,94 & 381,94 & 381,94 & 381,94 \\
Tempu & & & & \\
$\quad$ rung & 78,13 & 91,15 & 104,17 & 91,15 \\
$\begin{array}{l}\text { Sendok } \\
\text { Penam }\end{array}$ & 2,60 & 2,60 & 2,60 & 2,60 \\
pung & 625,00 & 625,00 & 703,13 & 51,04 \\
\hline
\end{tabular}

Total Nilai Penyusutan $\quad 1.607,06$

Tabel 5 memperlihatkan bahwa ratarata total penyusutan yang digunakan dalam produksi pada pengrajin 1 , pengrajin 2 , dan pengrajin 3 dalam pembuatan gula Aren adalah sebesar Rp. 1.607,06-. Penyusustan alat-alat produksi yang digunakan dipengaruhi oleh umur teknis, harga barang modal dan nilai sisa.

\section{Biaya Variabel (VC)}

Biaya variabel adalah biaya yang digunakan dalam satu kali proses produksi dan besar kecilnya biaya dipengaruhi oleh produksi yang diperoleh. dalam biaya variabel ini yang dihitung adalah biaya bahan baku, dan biaya transportasi, biaya tambahan/penolong seperti sabun cap kodok dan kayu bakar. Dalam penelitian ini dapat dilihat pada Tabel 6 .

Tabel 6 memperlihatkan bahwa biaya yang dikeluarkan dalam proses pembuatan gula aren yaitu biaya bahan baku adalah sebesar Rp. 35.690,24, biaya tenaga kerja adalah sebesar Rp. 66.000, biaya transportasi adalah sebesar Rp. 30.000 dan biaya tambahan untuk pembuatan gula aren yaitu biaya kayu bakar adalah

Tabel 6. Jenis dan Besar Biaya Variabel Produksi pada Pengrajin 1, Pengrajin 2, dan Pengrajin 3 Agroindustri Gula Aren.

\begin{tabular}{|c|c|}
\hline \multicolumn{2}{|c|}{$\begin{array}{c}\text { Biaya-biaya Produksi Rata-Rata Biaya } \\
(\mathrm{Rp})\end{array}$} \\
\hline Biaya Bahan Baku & $35.690,24$ \\
\hline Biaya Tenaga Kerja & 66.000 \\
\hline Biaya Transportasi & 30.000 \\
\hline \multicolumn{2}{|l|}{ Biaya Tambahan/Penolong } \\
\hline a. Kayu Bakar & 25.000 \\
\hline b. Sabun Cap Kodok & 208,33 \\
\hline Total Biaya Variabel & $156.898,57$ \\
\hline
\end{tabular}

sebesar Rp. 100.000/pengambilan kayu bakar dan dihitung dengan hasil pemakaian dalam $4 \mathrm{x}$ proses produksi dalam satu minggu sehingga biaya kayu bakar adalah sebesar Rp. 25.000, dan biaya sabun cap kodok adalah sebesar Rp. 10.000/bungkus. Sabun cap kodok digunakan dalam 48x pemakaian yaitu 4 bulan dalam proses produksi gula Aren, Sehingga dalam penelitian ini nilai sabun cap kodok adalah sebesar Rp. 208.33, Total rata-rata biaya variabel yang dikeluarkan adalah sebesar Rp. 156.898,57.

\section{Biaya bahan baku}

Biaya bahan baku dalam proses pembuatan gula aren ini merupakan salah satu komponen biaya produksi yang diperhitungkan, biaya bahan baku dalam pembuatan gula aren ini yaitu air nira. 
Dalam penelitian ini dapat dilihat pada Tabel 7.

Tabel 7 memperlihatkan bahwa biaya yang dikeluarkan dalam proses pembuatan gula aren yaitu biaya bahan baku air nira dengan jumlah (liter), harga, dan biaya dari pengrajin 1 , pengrajin 2 dan pengrajin 3 untuk pembuatan gula aren dengan total rata - rata biaya bahan baku yang dikeluarkan adalah sebesar Rp.35.690,24.

Tabel 7. Penggunaan Bahan Baku Air Nira yang digunakan pada Pengrajin 1, Pengrajin 2, dan Pengrajin 3 Agroindustri Gula Aren.

\begin{tabular}{lll}
\hline $\begin{array}{r}\text { Bahan Baku } \\
(\text { Liter })\end{array}$ & $\begin{array}{l}\text { Harga } \\
(\mathrm{Rp} / \mathrm{l})\end{array}$ & $\begin{array}{l}\text { Biaya } \\
(\mathrm{Rp})\end{array}$ \\
\hline Pengrajin 1 64 & 505,05 & $32.323,23$ \\
Pengrajin 2 72 & 505,05 & $36.363,64$ \\
Pengrajin 3 76 & 505,05 & $38.383,84$ \\
\hline \multicolumn{2}{l}{ Rata-Rata Biaya Bahan Baku } & $35.690,24$ \\
\hline
\end{tabular}

\section{Biaya Transportasi}

Dalam memasarkan hasil produksi ini tentunya memerlukan alat transportasi agar usaha ini tetap berjalan dan dalam memasarkannya. Alat transportasi yang digunakan berupa sepeda motor, dan dalam proses ini berarti memerlukan biaya sehingga diperhitungkan dalam komponen biaya produksi. Dalam sehari untuk memasarkan produk gula aren ini menggunakan sepeda motor (ojek) dalam proses pemasaran gula aren dengan biaya ojek Rp. 30.000 jadi total biaya pengeluaran transportasi adalah sebesar Rp.30.000/hari.

\section{Biaya Bahan Tambahan/Penolong}

Dalam proses ini biaya bahan tambahan juga diperhitungkan, dan biaya tambahan yang dihitung dalam proses memasak gula aren ini adalah biaya kayu bakar berjumlah Rp.100.000 dalam proses pemakaian selama satu minggu. dan menggunakan sabun cap kodok berharga
Rp.10.000/bungkus. Sabun cap kodok digunakan dalam $48 \mathrm{x}$ pemakaian yaitu 4 bulan dalam proses produksi gula Aren, Sehingga dalam penelitian ini nilai sabun cap kodok adalah sebesar Rp. 208.33. Jadi total biaya tambahan adalah Rp. 110.000.

Tabel 8 memperlihatkan bahwa Total biaya tetap yang dikeluarkan dalam proses pembuatan gula aren adalah sebesar Rp. 1.607,06, Total Biaya Variabel yang dikeluarkan dalam proses pembuatan gula Aren adalah sebesar Rp. 156.898,57.

Tabel 8. Total Rata-Rata Biaya Tetap, dan Total Rata-Rata Biaya Variabel pada Pengrajin 1, Pengrajin 2, dan Pengrajin 3 Agroindustri Gula Aren

\begin{tabular}{lc}
\hline Jenis Biaya & $\begin{array}{c}\text { Rata-rata } \\
\text { Biaya (Rp) }\end{array}$ \\
\hline Biaya Tetap (FC) & $1.607,06$ \\
Biaya Variabel (VC) & $156.898,57$ \\
\hline
\end{tabular}

\section{Penerimaan}

Penerimaan adalah jumlah produksi dikalikan dengan harga jual yang berlaku. Dalam kegiatan usaha ini selalu meningkatkan produksi dengan harapan bahwa pendapatan yang diterima akan naik sejalan dengan bertambahnya produksi yang dihasilkan. Penerimaan berkaitan erat dengan volume produksi dan harga jual, oleh karena itu penerimaan merupakan hasil perkalian antara harga jual yang berlaku dalam produksi. Dalam penelitian ini dapat dilihat pada Tabel 9.

Tabel 9. Rata-Rata Biaya Produksi dari Pengrajin 1, Pengrajin 2, dan Pengrajin 3 Agroindustri Gula Aren.

\begin{tabular}{|c|c|c|c|}
\hline & $\begin{array}{l}\text { Harga jual } \\
\text { (Rp/butir) }\end{array}$ & $\begin{array}{l}\text { Produksi } \\
\text { (butir) }\end{array}$ & $\begin{array}{l}\text { Penerimaan } \\
\text { (Rp) }\end{array}$ \\
\hline Peng. 1 & 8.000 & 30 & 240.000 \\
\hline Peng. 2 & 10.000 & 35 & 350.000 \\
\hline Peng. 3 & 10.000 & 50 & 500.000 \\
\hline Rata-R & ata $9.333,33$ & 38,33 & $363.333,33$ \\
\hline
\end{tabular}


Tabel 9 memperlihatkan bahwa biaya produksi pengrajin 1 , pengrajin 2 , dan pengrajin 3 dengan harga jual (Rp/gula batu), Produksi /(gula batu) dan Penerimaan (Rp). Dengan rata-rata harga jual pengrajin 1,pengrajin 2, dan pengrajin 3 adalah sebesar Rp. 9.333,33. Rata-rata Produksi pada pengrajin 1 , pengrajin 2 dan pengrajin 3 adalah sebesar Rp. 38,33 dan Rata-rata penerimaan pengrajin 1 , pengrajin 2 , dan pengrajin 3 adalah sebesar Rp. 363.333,33. Dengan total rata-rata biaya Penerimaan yang dikeluarkan dalam proses pembuatan gula aren adalah sebesarRp. 363.333,33

\section{Keuntungan}

Keuntungan yang diperoleh sangat tergantung dari jumlah penerimaan yang diterima dikurangi dengan biaya yang dikeluarkan, besarnya penerimaan yang didapat merupakan hasil perkalian antara harga jual produk dengan jumlah produksi yang dihasilkan sehingga tinggi produksi dengan biaya semakin kecil dan harga akan mempengaruhi keuntungan.

Dalam penelitian ini dapat dilihat bahwa Total Penerimaan, Total Biaya dan Total Keuntungan dari Pengrajin 1, Pengrajin 2, dan Pengrajin 3. Dengan Penerimaan sebesar Rp. 363.333,33, Biaya sebesar Rp. $158.505,63$, dan Keuntungan yang di dapat dalam proses pembuatan gula aren dalam satu kali proses produksi adalah sebesar Rp. 204.827,71-.

\section{Revenue Cost Ratio}

Tingkat keuntungan ekonomi dapat diketahui dengan menggunakan Analisis Revenue Cost Ratio ( $\mathrm{R} / \mathrm{C}$ ratio) adalah perbandingan antara penerimaan dan biaya, ratio yang menjadi parameternya adalah nilai $\mathrm{R} / \mathrm{C}=1$ berarti usaha tidak untung dan tidak rugi, nilai $\mathrm{R} / \mathrm{C}<1$ berarti usaha rugi, nilai $\mathrm{R} / \mathrm{C}>1$ berarti usaha untung. Nilai R/C Usaha Industri Gula Aren di Kelurahan Pandu Kecamatan Bunaken dapat dilihat bahwa nilai rata-rata $\mathrm{R} / \mathrm{C}$ dari produksi gula Aren ini menunjukan angka $>1$. Nilai R/C dari gula Aren ini adalah 2.29 maka usaha industri gula Aren ini menguntungkan.

\section{KESIMPULAN DAN SARAN}

\section{Kesimpulan}

Dari penelitian ini dapat disimpulkan bahwa usaha Agroindustri Gula Aren di Kelurahan Pandu Kecamatan Bunaken Kota Manado ini menguntungkan. Usaha Industri Gula Aren ini mengeluarkan total rata-rata biaya dalam sekali produksi adalah sebesar Rp. 158.505,63, total rata-rata penerimaan adalah sebesar Rp.363.333,33, dan mendapatkan total rata-rata keuntungan adalah sebesar Rp.204.827,71 dalam sekali produksi. dan menggunakan R/C Ratio menjadi 2,29 yang berarti industri ini menguntungkan.

\section{Saran}

Berkaitan dengan hasil penelitian yang didapat, maka petani usaha gula aren di Kelurahan Pandu layak untuk dikembangkan dan petani perlu meningktkan jumlah produksi sehingga mendapatkan keuntungan yang maksimal. Dan sebagai saran untuk pemerintah agar dapat memperhatikan usaha gula aren karena menguntungkan dan dapat meningkatkan kesejahteraan petani.

\section{DAFTAR PUSTAKA}

Anoraga, P. \& J. Sudantoko. 2002. "Koperasi Kewirausahaan dan Usaha Kecil. Rineka Cipta". Jakarta.

Djoyodiporo, 2002. "Keberpihakan Kepada Industri “. Penerbit Rosta Jaya Bandung.

Efendi, D.S. 2009. “Aren Sumber Energi Alternatif Warta Penelitian dan Pengembangan Pertanian". Tahun. 2009. Bogor.

Henry, S. 2013. "Pengantar Ilmu Ekonomi”. CAPS. Yogyakarta. 
Khazanani, A., SBM, N., \& Nugroho, S. B. M. Nugroho. "Analisis Efisiensi Penggunaan Faktor-Faktor Produksi Usahatani Cabai Kabupaten Temanggung" (Studi Kasus di Desa Gondosuli Kecamatan Bulu Kabupaten Temanggung). Diss. Universitas Diponegoro, 2011.

Kusnandar, F., 2010. "Kimia Pangan Komponen Makro". Penerbit Dian Rakyat, Jakarta.

Leatermia, E.D. 2008. "Analisis Finansial Usaha Agroindustri Gula Aren di Desa Tahaha Kecamatan Saparua. Maluku Tengah. Provinsi Maluku”. Jurnal Ichsan Gorontalo Vol. 3. No 1.

, 2009. “Akutansi Biaya”. Edisi Ke-5 Cetak Kesembilan. Penerbit UPPSTIM YKPN. Yogyakarta.

Nurahman, 2010. "Kajian faktor-faktor Internal dan Eksternal yang mempengaruhi Produktifitas Usaha Pengolahan Produk Agribisnis “. Jurnal ilmiah Departemen Ilmu Sosial Ekonomi IPB VOL., 3. No. 11

Nurlela, E . 2002. "Kajian Faktor-Faktor Yang Mempengaruhi Pembentukan Warna Gula Aren". (Doctoral dissertation, IPB (Bogor Agricultural University).

Priyono, 2011. "Analisis Kelayakan Finansial Usaha Pegolahan Gula Aren Secara Kelompok di Kanagarian Talang Maur Kecamatan Mungka Kabupaten Lima Puluh Kota Provinsi Sumatra Barat”. Jurnal Refiansyah Putra. Hal 2 Vol 1.
Rachman, B. 2009. "Karakteristik Petani dan Pemasaran Gula Aren di Banten". Forum Penelitian Agroekonomi (Vol. 27, No. 1, pp. 53-60).

Ryanto, B. 2010. “Analisis Laporan Keuangan”. Liberty. Yogyakarta.

Soekartawi. 2001. "Pengantar Agroindustri”. Jakarta. .2002. "Teori Ekonomi Pertanian". PT. Raja Grafindo Persada. Jakarta. , 2006. "Analisis Usaha Tani. UI Press. Jakarta.

Sukirno, S. 2002. "Pengantar Teori Makro Ekonomi”. PT. Raja Grafndo. Jakarta.

Syam, H., \& Maarif. M. S. 2004. "Kajian Perlunya Kebijakan Pengembangan Agroindustri Sebagai Leading Sektor".

Supriyono, R.A, 2000. “Akutansi Biaya". Perencanaan dan Pengendalian Biaya serta pembuatan keputusan, Edisi kedua, BPFE, Yogyakarta.

Simamora, 2000. "Akutansi”. Basis Pengembalian Keputusan Bisnis. Jild Satu. Salemba Empat. Jakarta.

Suratiyah, Ken. 2006. "Ilmu Usaha Tani". Jakarta. Penebar Swadaya.

Santoso, W., Utami, P. dan Dumasari. 2009. "Analisis Pendapatan dan Biaya Produksi Agroindustri Tahu di Desa Pandansari kecamatan Ajibarang Kabupaten Banyumas". Jurnal. Fakultas Pertanian. Universitas Muhammadiayah Purworkerto. 